\title{
A Standard for Tailoring Noerr- Pennington Immunity More Closely to the First Amendment Mandate
}

\author{
David L. Meyer
}

The Noerr-Pennington doctrine ${ }^{1}$ provides antitrust immunity for all genuine efforts to seek governmental action, regardless of whether the petitioning produces incidental injury to competition or the governmental action sought is legitimate ${ }^{2}$ and thus immune from antitrust liability. The doctrine's blanket protection of conduct offensive to the fundamental principles of antitrust law is not justified by First Amendment petitioning interests. This Note proposes that immunity not be granted when a group's petitioning produces unnecessary direct antitrust injury and the governmental action sought by the group is illegitimate. Such a rule would deter undesirable direct injury and would force groups to consider less-injurious alternatives when petitioning for anticompetitive results.

Section I outlines the existing body of law that defines the scope of Noerr-Pennington petitioning immunity. Section II identifies the two fundamental shortcomings in Noerr-Pennington analysis. Section III presents the criteria that any solution to these problems must meet and proposes such a solution.

\section{Petitioning Immunity Under Existing Law}

By enacting the Sherman Act, ${ }^{3}$ Congress "sought to establish a regime of competition as the fundamental principle governing commerce in this country." The Supreme Gourt has repeatedly held this basic policy to be of near-constitutional importance. ${ }^{5}$

In Eastern Railroad Presidents Conference v. Noerr Motor Freight,

1. The Noerr-Pennington doctrine derives from Eastern R.R. Presidents Conference v. Noerr Motor Freight, Inc., 365 U.S. 127 (1961), and United Mine Workers v. Pennington, 381 U.S. 657 (1965). See infra notes 6-17 and accompanying text.

2. "Legitimate" governmental action as discussed in this Note is that which is within government's proper discretion and authority and does not violate the Constitution or some other applicable body of law, including the federal antitrust laws.

3. 15 U.S.C $\$ \S 1-7$ (1982).

4. City of Lafayette v. Louisiana Power \& Light Co., 435 U.S. 389, 398 (1978) (footnote omitted).

5. See United States v. Topco Assocs., Inc., 405 U.S. 596, 610 (1972); Appalachian Coals, Inc. v. United States, 288 U.S. 344, 359-60 (1933). 
Inc. ${ }^{6}$ the Supreme Court first articulated an exemption from antitrust liability for joint efforts to influence governmental action. ${ }^{7}$ In Noerr, a group of railroads hired a public relations firm to conduct a publicity campaign designed in part to promote the adoption of state legislation injurious to the trucking industry. ${ }^{8}$ The Court found two specific bases for concluding that the Sherman Act did not forbid this activity. ${ }^{\circ}$ The first rested on the premise that "where a restraint upon trade or monopolization is the result of valid governmental action, as opposed to private action, no violation of the Act can be made out."10 Given that it is sometimes the legitimate function of government to restrain trade, the democratic quality of such governmental action "depends upon the ability of the people to make their wishes known to their representatives."11

The second basis of the Noerr holding was the First Amendment right to petition. ${ }^{12}$ The Court wrote: "The right of petition is one of the freedoms protected by the Bill of Rights, and we cannot, of course, lightly impute to Congress an intent to invade these freedoms."

6. 365 U.S. 127 (1961).

7. Section 1 of the Sherman Act proscribes only joint action ("contract, combination . . or conspiracy") in restraint of trade. 15 U.S.C. \& 1 (1982). Section 2 of the Sherman Act proscribes joint and individual behavior designed to monopolize. Id. § 2 . This Note addresses petitioning immunity for joint efforts to restrain trade, because those efforts account for virtually all situations dealt with in the case law. Many of the same issues are presented, however, by an individual firm's efforts to monopolize using the petitioning process.

8. The campaign was "designed to foster the adoption and retention of laws and law enforcement practices destructive of the trucking business, to create an atmosphere of distaste for the truckers among the general public, and to impair the relationships existing between the truckers and their customers." 365 U.S. at 129.

9. The Court also pointed to the "essential dissimilarity between an agreement jointly to seek legislation or Jaw enforcement and the agreements traditionally condemned by $\$ 1$ of the [Sherman] Act." Id. at 136. This argument was contrary to prevailing precedent, particularly when the joint petitioning caused direct anticompetitive injury, and has not been relied on by subsequent courts. See Fischel, Antitrust Liability for Attempts to Influence Government Action: The Basis and Limits of the Noerr-Pennington Doctrine, 45 U. CHI. L. REv. 80, 83 \& n.26 (1977). In the absence of immunity based on structural and constitutional petitioning interests, the antitrust laws would apply to this activity.

10. 365 U.S. at 136 (footnote omitted) (citing Parker v. Brown, 317 U.S. 341 (1943) (state action), and United States v. Rock Royal Co-Operative, Inc., 307 U.S. 533 (1939) (federal regulatory regime)).

11. 365 U.S. at 137.

12. "Congress shall make no law . . . abridging the freedom of speech, or of the press; or the right of the people peaceably to assemble, and to petition the Government for a redress of grievances." U.S. Const. amend. I.

13. 365 U.S. at 138. The Court noted, however, that "[b]ecause of the view we take of the proper construction of the Sherman Act, we find it unnecessary to consider [the First Amendment] defenses." Id. at 132 n.6. The question whether the Noerr decision rested solely on a construction of the Sherman Act in light of First Amendment concerns or directly on First Amendment grounds has been a subject of considerable debate. Compare Handler, Twenty-Five Years of Antitrust, 73 Colum. L. REv. 415, 434-35 \& n.142 (1973) (Noerr discussed First Amendment considerations as indicative of Congress' intent but did not reach constitutional question) with Fischel, supra note 9, at 84 n.32 (citing later decisions which viewed Noerr as First Amendment case).

The importance of both bases of petitioning immunity-the First Amendment and the government's need for information upon which to act-was underscored when the Noerr Court held that the an- 
opinions of the Court have relied directly on the First Amendment as a basis for extending Noerr-Pennington immunity. ${ }^{14}$

The doctrine fostered by Noerr essentially provides that all activities within the normal scope of petitioning which represent attempts to secure anticompetitive governmental responses are exempt from antitrust liability. ${ }^{15}$ The only uniformly accepted limitation to this immunity is the "sham" exception, which denies immunity for petitioning efforts that are merely veiled attempts to injure competitors directly ${ }^{18}$ or that use means that violate other laws to influence government. ${ }^{17}$

In the paradigmatic scenario the application of the Noerr-Pennington doctrine produces a desirable result. Governments sometimes may, under the antitrust laws, lawfully take actions that have anticompetitive results. ${ }^{18}$ When groups of competitors seek such governmental action, they cannot appropriately be said to "cause" the anticompetitive governmental response. ${ }^{19}$ Pure petitioning which threatens the competitive process only

ticompetitive purpose motivating the petitioning activity did not give rise to liability. Both interests relied upon by the Court are equally implicated when private parties are financially interested in a given result, and thus intend to have government injure competitors: "A construction of the Sherman Act that would disqualify people from taking a public position on matters in which they are financially interested would thus deprive the government, of a valuable source of information and, at the same time, deprive the people of their right to petition in the very instances in which that right may be of the most importance to them." 365 U.S. at 139. In subsequent cases the Supreme Court has referred explicitly to both considerations. See Lafayette, 435 U.S. at 399; California Motor Transp. Co. v. Trucking Unlimited, 404 U.S. 508, 510 (1972).

14. See Trucking Unlimited, 404 U.S. at 510-11 (although denying immunity under sham exception); Handler, supra note 13, at 435 (discussing Trucking Unlimited).

15. The Noerr-Pennington doctrine has been extended to petitioning before all forms of government bodies, including administrative officials, Pennington, 381 U.S. 657, 669-70, and adjudicatory tribunals, Trucking Unlimited, 404 U.S. at 510. At least one court has applied the doctrine to efforts to convince private organizations to adopt fire code standards and testing procedures which are often adopted or relied upon by state and local authorities. See Sessions Tank Lines, Inc. v. Joor Mfg., 54 U.S.L.W. 2393 (C.D. Cal. Jan. 21, 1986) (summarizing decision).

16. The possibility of a "sham exception" was first noted in Noerr when the Court indicated that "[t] ernmental action, is a mere sham to cover what is actually nothing more than an attempt to interfere directly with the business relationships of a competitor and the application of the Sherman Act would be justified." 365 U.S. at 144. Trucking Unlimited, 404 U.S. 508, was the first case to interpret and apply the sham exception. For a discussion of when petitioning efforts are "a mere sham," see infra notes 28-32 and accompanying text.

17. Examples of impermissible means of petitioning within the sham exception include fraud and misrepresentation before adjudicatory bodies, Clipper Exxpress v. Rocky Mountain Motor Tariff Bureau, Inc., 690 F.2d 1240, 1259-63 (9th Cir. 1982), cert. denied, 459 U.S. 1227 (1983), and threats or coercive activity, Sacramento Coca-Cola Bottling Co. v. Chauffeurs, Teamsters \& Helpers Local No. 150, 440 F.2d 1096, 1099 (9th Cir.), cert. denied, 404 U.S. 826 (1971).

Various courts have developed other exceptions to the general Noerr-Pennington immunity, including the "commercial" exception and the "co-conspirator" exception, discussed in some detail infra at notes 57-63 and accompanying text. For a recent and thorough analysis of Noerr-Pennington and its exceptions, see Kintner \& Bauer, Antitrust Exemptions for Private Requests for Governmental Action: A Critical Analysis of the Noerr-Pennington Doctrine, 17 U.C.D. L. REv. 549 (1984).

18. See supra note 10 and accompanying text; infra notes 53,65 , \& 98.

19. As Noerr recognized, the responsibility for deciding what kinds of laws should be passed or enforced properly remains with the appropriate body of government. 365 U.S. at 136. See Outboard 
through the government's response, and not through the petitioning itself, thus causes no legally cognizable injury, while serving the two interests upon which Noerr was predicated. ${ }^{20}$ Not all petitioning that qualifies for Noer-Pennington immunity, however, falls within this ideal scenario.

\section{GuRrent Structure of Immunity Tolerates ToO Much Direct Injury to the Competitive Process}

Relaxing the assumptions of the ideal model of Noerr-Pennington immunity reveals two significant problems with traditional analysis: The doctrine provides blanket immunity even when petitioning seeks an illegitimate governmental response or causes unnecessary direct injury to competition. Existing Noerr-Pennington doctrine thus ignores two factors that should be considered in assessing the desirability of direct injury incidental to the petitioning process.

The process of encouraging government to injure or regulate competitors, although within the current scope of Noerr-Pennington protection, often causes direct injury to competitors regardless of the ultimate course of action taken by the government. For example, when access to a market is contingent upon government approval, petitioning by groups of existing competitors, who have aggregated their economic power to protect the group, creates direct barriers to entry. ${ }^{21}$ Potential competitors therefore not only must incur the expenses normally associated with obtaining the necessary regulatory approval for market entry, but also must overcome

Marine Corp. v. Pezetel, 474 F. Supp. 168, 178 (D. Del. 1979) (agency decision not "product" of defendants' false statements before agency unless court assumed agency "made no independent factfinding but relied exclusively on the data submitted by interested private parties").

20. For apparent examples of this sort of ideal application of Noerr-Pennington, see Metro Cable Co. v. CATV of Rockford, Inc., 516 F.2d 220, 229 (7th Cir. 1975) ("II]njury to plaintiff . . . was caused by the governmental actions of the city council which the defendants genuinely and successfully attempted to induce the city council to take."); In Re Airport Car Rental Antitrust Litig., 521 F. Supp. 568, 574 (N.D. Cal. 1981) ("If plaintiff suffered injury, it resulted from the acts of public officials declining to lease space to plaintiff . . . not the joint action of defendants; that injury would have been the same had each defendant acted wholly independently in seeking to influence the authorities."), affd, 693 F.2d 84 (9th Cir. 1982), cert. denied, 462 U.S. 1133 (1983). Assuming that the governmental action taken in these cases was legal, this kind of joint petitioning should be encouraged. But see Note, Does the First Amendment Protect the Use of Lobbying Activities and Mass Communication to Obtain an Illegal Monopoly?, 19 U. PITT. L. REv. 777, 779-84 (1958) ("right to petition ought not to include the right to invoke the aid of state legislatures in order to" accomplish group's illegal aim of monopoly).

21. Commentators have pointed out the tremendous opportunities for predation through the use of governmental processes. See R. BoRk, The AntTrRust PARAdox 347 (1978) (in order to enter markets, businesses "must gain various types of approval from governmental agencies, departments, and officials," including "[l]icensing authorities, planning boards, zoning commissions, health departments, building inspectors, [and] public utilities commissions"); see also Woods Exploration \& Producing Co. v. Aluminum Co. of Am., 438 F.2d 1286, 1296-97 (5th Cir. 1971) ('P]olicies of the Sherman Act should not be sacrificed simply because defendants employ governmental processes to accomplish anti-competitive purposes. Otherwise, with governmental activities abounding about us, government could engineer many to antitrust havens."), cert. denied, 404 U.S. 1047 (1972). 
the combined resistance of existing competitors acting within that governmental process. By litigating, protesting before administrative bodies, and waging publicity campaigns, existing competitors can impose "direct injuries"-costs caused by the resulting delay, expenses incurred responding to the group's efforts, uncertainty among investors, and loss of potential customers-regardless of whether the government body is, in the end, persuaded to deny the new competitor's entry.

Groups of competitors can inflict these injuries whenever they seek governmental action that would injure competition. ${ }^{22}$ Moreover, when competitors aggregate their resources to petition for an anticompetitive result they can exert more leverage within the governmental process, and inflict more direct injury, than the same firms acting individually. ${ }^{23}$

22. The petitioning process itself will impose costs on competitors. They must either expend resources fighting back with petitioning of their own, find some other way to counteract the negative effects of the petitioning, or suffer financial and competitive loss. See, e.g., Kintner \& Bauer, supra note 17, at 550 ("very act of seeking governmental intervention, even if unsuccessful, may have adverse competitive effects"); Balmer, Sham Litigation and the Antitrust Laws, 29 Buffalo L. REv. 39, 63 (1980) (direct anticompetitive effects of predatory litigation include imposing high fixed costs on competitors and blocking financing); Blecher \& Bennett, Litigation as an Integral Part of a Scheme to Create or Maintain an Illegal Monopoly, 26 MERCER L. REv. 479, 480-81 (1975) (same); Note, Appeals to the Electorate by Private Businesses: Injury to Competilors and the Right to Petition, 70 YALE L.J. 135, 136 (1960) ("[E]ven if the attempt to influence government fails, the campaign to disenchant public officials with competitors may impair the competitors' market position, by casting aspersions on their business reputation.").

Because plaintiffs seeking to benefit from the sham exception must still establish the elements of an antitrust claim, including that the private defendants have caused antitrust injury, Brunswick Corp. v. Pueblo Bowl-O-Mat, Inc., 429 U.S. 477, 489 (1977), invocation of the sham exception has revealed a broad range of petitioning activity that causes this sor of "direct injury." See Hospital Bldg. Co. v. Trustees of Rex Hosp., 691 F.2d 678, 689 (4th Cir. 1982) (delay in approval of application for certificate of need), cert. denied, 464 U.S. 890, 464 U.S. 904 (1983); Clipper Exxpress v. Rocky Mountain Motor Tariff Bureau, Inc., 690 F.2d 1240, 1266-1267 (9th Cir. 1982) (defendant's sham protest of plaintiff's rate triggered ICC investigation that effectively barred publication of new rate, causing two-year delay; plaintiff incurred costs in defending against protests), cert. denied, 459 U.S. 1227 (1983); Subscription Television, Inc. v. Southern Cal. Theatre Owners Ass'n., 576 F.2d 230 (9th Cir. 1978) (advertisements to secure enactment of measure later held unconstitutional interfered with public offering, blocking financing efforts); Trucking Unlimited v. California Motor Transp. Co., 432 F.2d 755, 762 (9th Cir. 1970) ("As a direct result of defendants' joint activities, the financial resources of plaintiffs and other competitors of the defendants were depleted; applications by ... competitors for the issuance, transfer, or registration of operating rights were defeated, delayed, or restricted; and . . . competitors were deterred from instituting or pursuing such applications."), affd, 404 U.S. 508 (1972).

23. Combined efforts may achieve various scale economies in petitioning. Of course, such agreements among competitors that restrain trade directly are, if nothing else, the kind of behavior that the antitrust laws prohibit. Moreover, an agreement among competitors to contribute to a litigation or "petitioning" fund might involve collusive, yet undetectable, activity to earn supercompetitive returns in order to raise those funds, which firms behaving competitively would not have available.

On the other hand, it is likely that, at least in the legislative lobbying arena, society reaps gains from more thorough consideration of government policy decisions through the pooling of resources by individual enterprises. See Note, Application of the Sherman Act to Attempts to Influence Government Action, 81 HARV. L. REv. 847, 849 (1968). To the extent that these benefits of group action are limited to the "lobbying" context or other situations in which the government is legally able to take the action sought, they will not be impinged by the solution proposed by this Note. See infra text accompanying notes $74 \& 98$. 


\section{A. Existing Doctrine Makes No Inquiry into Necessity to Petitioning In- terests of Direct Injury}

Although the sham exception to Noerr-Pennington immunity recognizes, and is in part designed to reach, these sorts of direct injury, ${ }^{24}$ it is impossible to characterize petitioning that is intended to produce these harmful results as "sham" activity when petitioners are also genuinely seeking a governmental response. ${ }^{25}$ The Noerr Court thus correctly interpreted the Sherman Act not to outlaw all direct injury. The Court went further, however, and precluded any consideration of the extent of the direct injury inflicted by petitioners in determining whether immunity should be granted. ${ }^{28}$ Noerr's approach has been followed uniformly: without a finding that petitioning activity is merely a pretext for inflicting direct injury, and thus a sham, direct anticompetitive injury will not lead to antitrust liability. ${ }^{27}$

Because it essentially ignores the possibility of direct injury, the current Noerr-Pennington standard of immunity is overly broad in two respects. First, because the doctrine only considers the genuineness of petitioning, it automatically shields from liability all petitioning that causes direct injury unless there is no "genuine effort" to influence governmental action, even if the petitioners foresee and intend the direct injury. ${ }^{28}$ Defendants, however, will always desire to have the government respond to their petitioning by taking action that is harmful to competitors, ${ }^{29}$ and courts cannot

24. Applying the sham exception, the Court in Trucking Unlimited noted that "[a] combination of entrepreneurs to harass and deter their competitors from having 'free and unlimited access' to the agencies and courts, to defeat that right by massive, concerted, and purposeful activities of the group are ways of building up one empire and destroying another." 404 U.S. at 515.

25. The Noerr case itself illustrates this problem. Despite allegations of direct injury to the business relationships of the truckers, the Court found that this sort of injury is often inevitable even in genuine petitioning activity: "To hold that the knowing infliction of such injury renders the campaign itself illegal would thus be tantamount to outlawing all such campaigns." 365 U.S. at 143-44.

26. The Court noted that "the findings of the District Court that the railroads' campaign was intended to and did in fact injure the truckers in their relationships with the public and with their customers can mean no more than that the truckers sustained some direct injury as an incidental effect of the railroads' campaign to influence governmental action and that the railroads were hopeful that this might happen." Id. at 143 (emphasis added) (footnote omitted).

27. See, e.g., Franchise Realty Interstate Corp. v. San Francisco Local Joint Exec. Bd. of Culinary Workers, 542 F.2d 1076, 1080 (9th Cir. 1976) (petitioning "absolutely immune"), cert. denied, 430 U.S. 940 (1977).

28. See New Motor Vehicle Bd. v. Orrin W. Fox Co., 439 U.S. 96, 110 n.15 (1978); Mark Aero, Inc. v. Trans World Airlines, 580 F.2d 288, 294-96 (8th Cir 1978); Franchise Realty, 542 F.2d at 1081 (actions taken with intent to injure competitor protected from liability unless "'nothing more' than an attempt to interfere with the business relationships of a competitor"). But see Coastal States Marketing, Inc. v. Hunt, 694 F.2d 1358, 1372 (5th Cir. 1983) ("genuine desire for judicial relief" must be "significant motivating factor underlying the suit") (emphasis added).

29. In the licensing context, for example, an association of existing competitors will naturally be most happy if the licensing authority turns down an application, even if their decision to protest was based entirely on anticipated direct injury. The Coastal States court specifically recognized that "mixed motives... usually actuate human conduct." 694 F.2d at 1372. 
effectively distinguish between a bona fide hope that such a response will be forthcoming and a "mere sham to cover what is actually nothing more than an attempt to interfere directly." 30 Therefore, in the absence of evidence of extreme bad faith ${ }^{31}$ the existing sham exception simply will not protect competition from the direct injury caused by petitioning. ${ }^{32}$

Consequently, the Noerr-Pennington doctrine does not precisely distinguish between the portion of petitioning that is genuinely motivated and that which would not occur but for the direct anticompetitive effects. In situations where there is some genuine hope that the government will be convinced to act, but where a portion of the petitioning would not have occurred if this hope were all that the group could expect, existing law clearly tolerates too much direct injury. The sham exception demonstrates that any inquiry into "genuineness" is ineffective as a means of identifying excessive injury.

Beyond the overreliance on the "genuineness" inquiry, the NoerrPennington doctrine is too broad for a second reason. Even when there is an entirely genuine motive for petitioning, and the direct injury is truly incidental, petitioning often causes more direct injury than is necessary to protect the interests articulated in Noerr. This problem arises because the immunity doctrine does not inquire into the existence of alternative means of petitioning that would cause less injury. ${ }^{\text {ss }}$ Where the alternatives are

30. Greenwood Utilities Comm'n v. Mississippi Power Co., 751 F.2d 1484, 1498 (5th Cir. 1985) (quoting Noerr, 365 U.S. at 144). The Greenwood court noted that "[t]he problem stems in part from the fact that determining whether the petitioning conduct was a sham often involves questions of motive or subjective intent." Id. at 1498 n.9.

31. Examples of such extreme cases include a consistent pattern of claims without any legitimate basis. See Trucking Unlimited, 404 U.S. at 513 ("pattern of baseless, repetitive claims may emerge which leads the factfinder to conclude that the administrative and judicial processes have been abused"); Clipper Exxpress, 690 F.2d at 1253 ("protests were spurious, baseless, and prosecuted without regard to their merit, intended only to delay competitive action, not to influence governmental action").

32. See, e.g., Mid-Texas Communications Sys. v. American Tel. \& Tel. Co., 615 F.2d 1372, 1384 \& n.9 (5th Cir.) (advocating narrow reading of sham exception "to protect the first amendment right of access to administrative proceedings," court found that defendant's opposition of competitor's complaint before FCC was not sham because plaintiff did not allege "a consistent pattern"), cert. denied, 449 U.S. 912 (1980); see also Note, The Misapplication of the Noerr-Pennington Doctrine in NonAntitrust Right to Petition Cases, 36 STAN. L. REv. 1243, 1254-55 \& n.54 (1984) ("courts typically offer antitrust immunity to virtually any petitioning").

33. There is often a range of petitioning methods capable of convincing the government to act in a certain way. An example was presented by Noerr itself. The railroads need not have used the "thirdparty technique," which involved misrepresentation, in order to influence the passage of laws injurious to truckers. 365 U.S. at 133. Many other harmless, albeit possibly less effective, petitioning methods were available, including direct lobbying of the Pennsylvania legislature. Similarly, when one protest of a rate request or licensing application by a group of competitors triggers agency adjudication, additional protests by individual members of the group serve only to increase the expenses incurred in defending against the protests. Also, when a group of competitors engages in boycotts or refusals to deal in order to force a favorable legislative response, rather than appealing to the legislature within the political ("lobbying") process, they cause injury to the competitive process that is not necessary to the "petitioning" aims of the group. Under some circumstances, however, this kind of "petitioning" through marketplace activity might not be protected under current law. See Mid-Texas, 
less effective but the loss of effectiveness is outweighed by a decrease in the amount of direct injury inflicted, society would be better off if the petitioners chose less harmful alternative methods of achieving their legitimate aims of influencing government.

The absolute rule embodied in existing Noerr-Pennington doctrine that ignores direct injury when a genuine petitioning motive is present and makes no inquiry into less-injurious alternatives is neither desirable nor constitutionally mandated. Although as peaceful activity conveying some expressive content, the form in which the petitioning activity addressed by any immunity standard is undertaken deserves some First Amendment protection, ${ }^{34}$ the activity remains subject to reasonable restrictions that address the injury that petitioning conduct produces. ${ }^{35}$

As the Court held in United States $v . O^{\prime} B r i e n,{ }^{36}$ government regulation incidentally affecting First Amendment freedoms is permitted if it "furthers an important or substantial governmental interest; if the governmental interest is unrelated to the suppression of free expression; and if the incidental restriction on alleged First Amendment freedoms is no greater than is essential to the furtherance of that interest." ${ }^{\text {"37 }}$ Regulations aimed at harmful, non-communicative impacts of expressive conduct that nonetheless have adverse effects on communicative opportunities are upheld as long as they do not unduly restrict the flow of information. ${ }^{38}$

The regulation involved here, the Sherman Act interpreted as including some form of petitioning immunity, clearly furthers an important governmental interest unrelated to the suppression of free speech: the interest in preventing direct anticompetitive injury. The Supreme Court has recognized that this interest is strong enough to justify some regulation that implicates First Amendment rights. ${ }^{38}$

615 F.2d at 1382-83 (Noerr-Pennington does not apply to actions in "essentially private context" such as defendant's "decision to refuse interconnection [which] was not directed toward any government agency or official").

34. See NAACP v. Claiborne Hardware Co., 458 U.S. 886, 911-12 (1982). In cases such as Claiborne, the Supreme Court has applied "standard speech clause analysis" to the right to petition. Note, supra note 32 , at 1248 .

35. That prohibited conduct involves protected activity does not end the inquiry into the constitutionality of the restraint. See Claiborne, 458 U.S. at 912 . Because First Amendment antitrust immunity was judicially created to avoid constitutional invalidation of the Sherman Act, courts are free to reconcile the conflicting policies to narrow that immunity rather than being constrained by the text of the statute.

36. 391 U.S. 367 (1968).

37. Id. at 377 .

38. See Grayned v. City of Rockford, 408 U.S. 104, 119 (1972) (upholding ordinance barring noisy demonstrations on streets abutting schools as not "unnecessarily interfer[ing] with First Amendment rights"); Cox v. New Hampshire, 312 U.S. 569, 574 (1941) ("the question . . . is whether [a] control is exerted so as not to deny or unwarrantedly abridge the right of assembly and the opportunities for the communication of thought").

39. See Claiborme, 458 U.S. at 912 (recognizing "strong governmental interest in certain forms of economic regulation [including prohibition against anticompetitive boycotts], even though such regula- 
A standard that considers the availability of less-injurious petitioning alternatives complies with the $O^{\prime} B r i e n$ requirement that the regulation not unduly restrict the flow of information. When such alternatives allow petitioners to exercise the expressive aspects of their petitioning efforts, the direct injury caused by these efforts is the proper subject of antitrust liability. The availability of such alternatives has consistently led courts to validate restrictions on methods of expression that cause harmful effects which the government seeks to regulate, even where the alternatives are somewhat less effective in furthering the speaker's interests. ${ }^{40}$ Moreover, these regulations have been upheld even though they require potential speakers to bear expense and delay in getting a license or trying to find an alternative site. ${ }^{41}$ The "First Amendment does not guarantee the right to communicate one's views at all times and places or in any manner that may be desired."42 Thus, the First Amendment does not compel an immunity standard that ignores direct injury when the injury tolerated is unnecessary to the fulfillment of structural and constitutional petitioning interests. ${ }^{43}$

tion may have an incidental effect on rights of speech and association"); National Soc'y of Professional Eng'rs v. United States, 435 U.S. 679, 697 (1978) ("While the resulting order may curtail the exercise of liberties that the Society might otherwise enjoy, that is a necessary and, in cases such as this, unavoidable consequence of the [antitrust] violation. . . . The First Amendment does not 'make it ... impossible ever to enforce laws against agreements in restraint of trade . . . ".") (quoting Giboney v. Empire Storage \& Ice Co., 336 U.S. 490, 502 (1949)). See also Trucking Unlimited, 404 U.S. 508 (recognizing this interest when applying sham exception). The Court has also explicitly recognized that the Congress has the power to regulate those who influence it. United States v. Harriss, 347 U.S. 612, 625-26 (1954) (Congress" interest in evaluating "pressures to which [its members] are . . subjected" justified requirement that lobbyists register and disclose activities).

40. Virginia State Bd. of Pharmacy v. Virginia Citizens Consumer Council, Inc., 425 L.S. 748, 771 (1976) ("We have often approved [time, place and manner] restrictions . . . provided that . . . they leave open ample alternative channels for communication of the information.") (collecting cases). Because speakers have litigated these cases, the "alternative channels" are necessarily not those that speakers would otherwise choose; courts have thus upheld regulations requiring speakers to convey their messages in less effective ways. See, e.g., Members of the City Council v. Taxpayers for Vincent, 466 U.S. 789, 812 (1984) (despite claim that posters had special advantages, Court found that "there is no reason to believe that these same advantages cannot be obtained through other means"); Heffron v. International Soc'y for Krishna Consciousness, Inc., 452 U.S. 640, 653 (1981) (upholding State Fair Rule that prohibited distribution of literature except from licensed booth location, although group claimed that success in achieving sales and donations depended on "intercepting fair patrons as they moved about"); Lloyd Corp. v. Tanner, 407 U.S. 551, 566-67 \& n.12 (1972) (in upholding arrests of veterans distributing handbills inside shopping center, Court noted existence of adequate alternative locations on streets and sidewalks outside center).

41. See, e.g., Harriss, 347 U.S. at 625 (prior information disclosure required by "those who for hire attempt to influence legislation or who collect or spend funds for that purpose"); Cox v. New Hampshire, 312 U.S. at 576 (upholding scheme providing for "license to march . . . after a required investigation... [and subject to] such conditions or changes in time, place and manner as would avoid disturbance" "); see also supra note 40.

42. Heffron, 452 U.S. at 647.

43. See Note, supra note 32, at 1262 (Right to petition deserves "no more protection" than other First Amendment rights, and "[t]he approach of many of the new Noerr-Pennington cases, automatically invoking absolute immunity for petitioning activity, should therefore be abandoned in nonantitrust cases as inconsistent with the Supreme Court's first amendment jurisprudence."). 


\section{Tailoring Noerr-Pennington Immunity}

This is especially true where, as here, regulating directly injurious petitioning does not threaten what many view as the essence of the free speech interest: the ability of an individual to express his views free from state coercion. ${ }^{44}$ Rather, even entirely genuine petitioning efforts involve collusive activity by business enterprises to seek economic gain in the marketplace through government-created competitive advantages. ${ }^{45}$ These efforts will often do as much to stifle as to enrich the public debate. ${ }^{18}$

\section{B. Existing Immunity Standard Makes No Inquiry into Legitimacy of Governmental Action Sought}

The Noerr analysis also fails to achieve an efficient result when the governmental action sought is not "legitimate." the petitioning activity is less highly valued under the first basis of Noerr - the need for communication from the people to the government. ${ }^{48}$

44. As corporate speech, joint anticompetitive petitioning does not implicate personal "selffulfillment" interests. In First Nat'l Bank v. Belloti, Justice White, writing in dissent, remarked that "what some have considered to be the principal function of the First Amendment, the use of communication as a means of self-expression, self-realization, and self-fulfillment, is not at all furthered by corporate speech." 435 U.S. 765, 804-05 (1978) (White, J. dissenting) (footnote omitted). In holding that corporations do possess First Amendment rights even when speaking on matters outside their economic interest, the majority relied on other grounds-namely the social interest in free public access to discussion and debate (the "free flow" of information) regarding the passage of a valid law-and thus did not question Justice White's conclusions. Id. at 783.

45. See infra note 94. This economic motivation also means that would-be petitioners will carefully plan their "petitioning," and be aware of the many alternative methods of achieving their goals of economic gain. See infra notes $85 \& 95$.

46. Anticompetitive petitioning by groups of large, existing corporations may overpower small, independent competitors in the political process and thereby derogate the constitutional rights of others. See Harriss, 347 U.S. at 625 ("voice of the people may all too casily be drowned out by the voice of special interest groups" absent regulation of those wishing to influence government); Kaler, The Sham Exception to the Noerr-Pennington Antitrust Immunity: Its Potential for Minimizing Anticompetitive Abuse of the Administrative Regulatory Process, 12 U. ToL. L. REv. 63, $91 \mathrm{n} .177$ (1980); of. Associated Press v. United States, 326 U.S. 1, 20 (1945) ("Freedom to publish means freedom for all and not for some. Freedom to publish is guaranteed by the Constitution, but freedom to combine to keep others from publishing is not."). But see Buckley v. Valeo, 424 U.S. 1, 48-49 (1976) (per curiam) ("concept that government may restrict the speech of some elements of our society in order to enhance the relative voice of others is wholly foreign to the First Amendment").

One branch of the sham exception recognizes the possibility that petitioning by a group can block meaningful access of competitors to the relevant adjudicatory process. See Clipper Exxpress, 690 F.2d at 1257-59. Such "access-barring," of course, can occur whether or not defendants' petitioning is a sham intended only to bar access.

47. For examples of illegitimate governmental action, see Community Communications Co. v. City of Boulder, 455 U.S. 40 (1982) (city's regulation of entry into cable television industry within its authority under "home rule" statute violates Sherman Act because of insufficiently clear state policy to displace competition); Subscription Television, Inc. v. Southern Cal. Theatre Owners Ass'n., 576 F.2d 230 (9th Cir. 1978) (anti-pay television initiative drafted and publicized by defendants and passed in general election subsequently declared unconstitutional); Society of the Plastics Indus., Inc. v. City of New York, 68 Misc. 2d 366, 374-75, 326 N.Y.S.2d 788, 797 (N.Y. Sup. Ct. 1971) (statute authorizing city to impose tax on sale of containers did not authorize tax on plastic containers only).

48. See Kurek v. Pleasure Driveway and Park Dist., 557 F.2d 580, 593 (7th Cir. 1977) ("Our determination that the Park District and its officials had no state mandate or authority to engage in the activities attacked here necessarily reduces the applicability of the reasoning of Noerr to the degree 
Efforts directed at encouraging government bodies to act in illegitimate ways are of little benefit because they provide no information upon which such bodies are legally able to act. ${ }^{40}$ Immunizing such efforts is justifiable only under a First Amendment rationale emphasizing society's interest in the free expression of citizens; ${ }^{50}$ this interest, however, is less compelling when the speech advocates illegal activity. ${ }^{51}$ Petitioning that seeks illegitimate governmental responses does not participate in the democratic process; rather it advocates action which higher democratic bodies, most notably the United States Congress, have already determined will not be permitted. ${ }^{52}$

Courts have not dealt in a uniform manner with the problem of petitioning to solicit illegitimate governmental action. Several courts have granted Noerr-Pennington immunity in the face of a determination either that Parker immunity ${ }^{63}$ - which protects state action from antitrust liabil-

it is based on the need of governmental units for citizen input in making decisions that Parker holds to be outside the scope of the Sherman Act."), vacated, 435 U.S. 992, reinstated, 583 F.2d 378, 379 (7th Cir. 1978), cert. denied, 439 U.S. 1090 (1979); Affiliated Capital Corp. v. City of Houston, 519 F. Supp. 991, 1025 (S.D. Tex. 1981) (illegality of conduct of government officials rendered legislative action sought by private parties invalid and weakened "first underpinning of Noerr"), rev'd on other grounds, 735 F.2d 1555, 1567 (5th Cir. 1984), cert. denied, 106 S. Ct. 788 (1986).

49. This is so unless the informational value of such petitioning were viewed as stemming from information provided to governments that convinces them not to take an invalid course of action. The petitioning at issue, however, will be attempting to induce precisely this invalid result, by either ignoring or concealing the impermissibility of the desired action.

50. See Fischel, supra note 9, at 101. ("That the petitioning activity is of no value to the government does not mean that the petitioning is of no legitimate value to the petitioner and his cocitizens.").

51. For example, speech that is "directed to inciting or producing imminent lawless action and is likely to incite or produce such action," Brandenburg v. Ohio, 395 U.S. 444, 447 (1969), or speech that encourages commission of a crime, Fox v. Washington, 236 U.S. 273 (1915), can form the basis for criminal liability. Although these doctrines usually involve the knowing advocacy of activity that is seemingly more dangerous than the illegal government activity sought by petitioning, they reflect a recognition that the illegality of the aim sought diminishes the First Amendment interests in protecting the speech. $C f$. Virginia State Bd. of Pharmacy v. Virginia Citizens Consumer Council, Inc., 425 U.S. 748, 772 (1976) ("no claim that the transactions proposed . . . are themselves illegal").

Analogous reasoning led the Supreme Court in Gertz v. Robert Welch, Inc., 418 U.S. 323, 340 (1974), to recognize that "the erroneous statement of fact is not worthy of constitutional protection," and that despite the inevitability of such statements in "free debate," id., states may impose liability for false statements made about private individuals "so long as they do not impose liability without fault." Id. at 347. Because advocacy of invalid governmental action is no more valuable than are false statements of fact and, as in Gertz, deserves protection only to avoid unduly cautious exercise of protected petitioning, id. at 340 , the Gertz holding allowing states to require speakers to exercise reasonable care in avoiding false statements suggests that it is equally permissible to require petitioners to undertake some efforts to ascertain whether invalid governmental action is sought. See infra note 99 and text accompanying note 100 .

52. Advocacy of illegitimate governmental action does not involve efforts to change laws, but only efforts to have government ignore existing legal limits to its power. See supra note 48 and accompanying text; BeVier, The First Amendment and Political Speech: An Inquiry Into the Substance and Limits of Principle, 30 Stan. L. REv. 299, 310-11 (1978).

53. See City of Lafayette v. Louisiana Power \& Light Co., 435 U.S. 389, 391 (1978) ("Parker v. Brown, 317 U.S. 341 (1943), held that the federal antitrust laws do not prohibit a State 'as sovereign' from imposing certain anticompetitive restraints 'as an act of government.'”). 


\section{Tailoring Noerr-Pennington Immunity}

ity-should be denied or that the governmental action sought was otherwise illegitimate. ${ }^{54}$ Other courts, however, have indicated that NoerrPennington immunity may be conditioned to some extent on the legitimacy of the governmental action taken. ${ }^{58}$ Indeed, language in both Noerr and Trucking Unlimited ambiguously suggests that petitioning immunity may protect only efforts to induce valid governmental action. ${ }^{56}$

Two lines of cases have articulated narrow exceptions to Noerr immunity that seem to base a denial of immunity to some extent on the illegitimacy of the governmental action sought. Some lower courts have applied a "commercial" exception to Noerr immunity. ${ }^{\text {"7 }}$ These courts have recognized that attempts to convince government officials to take illegitimate action when they are acting in their role as purchasers or sellers of goods and services, rather than as policy-makers, ${ }^{58}$ are not deserving of NoerrPennington's First Amendment protections. Where the political process has determined that a government official must undertake commercial dealings in a certain manner, attempts to induce the official to ignore that pre-determined policy have not been protected by Noerr-Pennington. ${ }^{50}$

54. See, e.g., In Re Airport Car Rental Antitrust Litig., 693 F.2d 84, 87 (9th Cir. 1982) (Parker and Noerr-Pennington "two separate doctrines") (quoting New Mexico v. American Petrofina, Inc., 501 F.2d 363, 368 n.11 (9th Cir. 1974)), cert. denied, 462 U.S. 1133 (1983); Subscription Television, 576 F.2d at 232-33 (Noerr-Pennington applies although "initiative" sought by defendants ultimately held unconstitutional); see also George R. Whitten, Jr., Inc. v. Paddock Pool Builders, Inc., 424 F.2d 25, 29 n.4 (1st Cir.) (although ultimately denying Noerr immunity, court approved of separate treatment of Parker and Noerr-Pennington doctrines), cert. denied, 400 U.S. 850 (1970).

55. See, e.g., Independent Taxicab Drivers' Employees v. Greater Houston Transp. Co., 760 F.2d 607, 613 n.10 (5th Cir.) ("IT) Parker and Noerr-Pennington immunities are somewhat interrelated. We need not consider, however, whether the private [defendant] would have prevailed with equal ease on summary judgment if the City had not been exempt under Parker."), cert. denied, 106 S. Ct. 231 (1985); see also Bern, The Noerr-Pennington Immunity for Petitioning in Light of City of Lafaycte's Restriction on the State Action Immunity, 1980 ARIz. ST. L.J. 279, 289-296 (discussing cases that suggest that Noerr might be conditioned on Parker); Comment, The Airport Car Rental Concessions: The Role of City of Lafayette v. Louisiana Power and Light Co. in Restricting Threats to Free Competition, 14 CAL. W.L. REv. 325, 351 (1978) (concluding, although with little analysis, that Noerr exemption is predicated upon valid governmental action being sought). See also infra note 62.

56. See Trucking Unlimited, 404 U.S. at 515 ("If the end result is unlawful, it matters not that the means used in violation may be lawful."); Noerr, 365 U.S. at 136 (whole analysis predicated on fact that "result of valid governmental action" is immune).

57. See, e.g., City of Atlanta v. Ashland-Warren, Inc., 1982-1 Trade Cas. (CCH) I 64,527, 72,928 (N.D. Ga. 1981) (court held Noerr immunity should not be applied "where the government is not operating in a policy making role, such as in the case where the government is acting as a consumer in the marketplace" soliciting bids for contracts).

58. It is clear that "whether the State is engaged in a commercial enterprise is relevant in determining the State's liability under Parker." Airport Car, 693 F.2d at 87.

59. See, e.g., Hecht v. Pro-Football, Inc., 444 F.2d 931, 942 (D.C. Cir. 1971) (because Armory Board was operating in marketplace as lessor of sports stadium, restrictive covenant in lease denying stadium access to lessee's competitors therefore was subject to antitrust laws; court held "the governmental agency . . . was obligated to carry out the policy [of competition] as already made, hence the rationale of Noerr-Pennington, guaranteeing access of private parties . . . to influence such agency simply did not apply"), cert. denied, 404 U.S. 1047 (1972); Whitten, 424 F.2d at 33 (where state legislature decreed "that government purchases will be made according to strictly economic criteria," 
On the other hand, several courts have explicitly rejected such a commercial exception. ${ }^{60}$ Even when applied, this commercial exception is necessarily limited to dealings with the government as buyer or seller, and thus represents only a limited departure from courts' refusal to condition $\mathrm{No}$ err-Pennington immunity on the legitimacy of the governmental action sought.

Another line of lower court cases has developed a doctrine that denies defendants Noerr-Pennington immunity when the government officials involved are themselves co-conspirators in the illegal scheme to restrain trade, ${ }^{61}$ and thus have no official immunity. ${ }^{62}$ But these courts have applied this "co-conspirator exception" only when there has been some agreement between the government officials and the private parties to exclude or harm competitors. ${ }^{63}$ The exception represents further recognition

private defendant was "free to seek legislative change in this basic policy" but not to encourage "officials who administer the bid statutes" to violate that policy).

60. See Greenwood Utilities Comm'n v. Mississippi Power Co., 751 F.2d 1484, 1505 (5th Cir. 1985) (rejecting exception although "intuitively appealing"); Airport Car, 693 F.2d at 87-88 (noting that rationale of Hecht and Whitten may have been implicitly oversuled by extension of NoerrPennington to adjudicatory bodies, which are required to enforce pre-existing policies, in Trucking Unlimited).

61. See, e.g., Mason City Center Assocs. v. City of Mason City, 468 F. Supp. 737, 744-46 (N.D. Iowa 1979) (collecting relevant cases and applying exception to allegation that private developers entered into anticompetitive agreement with city and city council acting beyond legal scope of their state delegated zoning powers "to exclude competing developers from the relevant market"). See generally Kintner \& Bauer, supra note 17, at 585-87 (discussing co-conspirator exception).

62. Under Parker $v$. Brown and its progeny, immunity is not granted to state action if the state has entered into a conspiracy with private parties in restraint of trade, rather than imposing the restraint as an act of government. 317 U.S. 341, 351-52 (1943). In some of its applications, therefore, the "co-conspirator" exception to Noerr-Pennington seems to impose liability on petitioners whenever the desired governmental action will be invalid. For example, in Duke \& Co. v. Foerster, 521 F.2d 1277 (3d Cir. 1975), the court faced an alleged agreement between corporations and municipal facilities to boycott plaintiff's product. After holding that "this is not a case where Parker-type immunity should be extended," id. at 1281, the court concluded that Noerr-Pennington immunity of private defendants is available only when "the public body acts within its legal discretion and in what it considers the public interest." Id. at 1282.

Other courts seem to apply a sham rationale to the co-conspirator exception, holding, in effect, that petitioners are not immune when they are aware that the desired result is an illegal conspiracy. See Greenwood Utilities, 751 F.2d at 1500 (viewing "proof of a conspiracy with government officials" as one component of sham exception); Affiliated Capital Corp. v. City of Houston, 519 F. Supp. 991, 1025 (S.D. Tex. 1981) (evidence demonstrated "not only that public officials actively participated in an illegal conspiracy but also that the private parties involved were aware of and sought such participation"), rev'd on other grounds, 735 F.2d 1555, 1567 (5th Cir. 1984), cert. denied, 106 S. Ct. 788 (1986).

63. See Duke, 521 F.2d at 1278 (municipal operator of public facilities agreed to buy male beverages from defendants and to boycott plaintiffs' products); Affiliated Capital, 519 F. Supp. at 1016 (Mayor was "active co-conspirator not content merely to accede to the wishes of private parties," and councilmen and other agents of the city were "vigorous[ly] involve[d] in orchestrating certain aspects of the conspiracy.").

Courts have not resolved the difficult question of what represents a complicitous governmental agreement to restrain trade as opposed to a successful petitioning effort where the government does what private parties ask. See Greenwood Utilities, 751 F.2d at 1500 . The Duke analysis reveals a fundamental problem with the co-conspirator exception: That private parties merely succeed in convincing government to take valid action should not form a sufficient basis for imposing liability. See 


\section{Tailoring Noerr-Pennington Immunity}

that petitioning government is not always protected when it seeks illegal governmental responses in the form of complicitous agreements to restrain trade. The co-conspirator exception, however, does not suggest that immunity for private petitioners will generally be based on the validity of the governmental action sought.

By not predicating petitioning immunity on the legitimacy of the governmental action sought, the Noerr-Pennington doctrine tolerates activity of little social utility, some of which inevitably produces direct injury to competitors. The expansion of Noerr to all branches of government ${ }^{34}$ and the recent limitations placed on the antitrust immunity of governments ${ }^{65}$ make the impact of the imperfections in the Noerr analysis substantial. Anticompetitive actions, such as licensing decisions, taken by local government bodies and the regulatory systems, such as zoning boards and price regulation regimes, set up by state and local governments are frequently denied Parker immunity from federal antitrust laws, even when those governments acted within their ostensible authority and discretion. ${ }^{68}$ Thus, private efforts to convince governments to set up these regulatory and licensing regimes or to induce the regulatory bodies to take certain actions are often directed at "illegitimate" governmental action, and they

Metro Cable Co. v. CATV of Rockford, Inc., 516 F.2d 220, 230 (7th Cir. 1975). For this reason Fischel, supra note 9, at 115, concludes that "[a]lthough the [co-conspirator] exception may have some utility . . . in most cases [it] is unworkable and should not be recognized." However, Metro Cable and Fischel do not address the situations faced in Duke and Affiliated Capital, where the petitioners were not only successful, but the courts also concluded that the government unit's actions were outside the scope of Parker immunity.

64. See supra note 15.

65. "Parker immunity is available to private parties, and to state agencies or officials regulating the conduct of private parties" only if the challenged regulatory activity is "clearly articulated and affirmatively expressed as state policy" and any private anticompetitive conduct undertaken pursuant to the regulatory scheme is actively supervised by the state itself. Southern Motor Carriers Rate Conference, Inc. v. United States, 105 S. Ct. 1721, 1727 (1985) (quoting and applying the twopronged test of California Retail Liquor Dealers Ass'n v. Midcal Aluminum, Inc., 445 U.S. 97, 105 (1980), quoting in turn City of Lafayette v. Louisiana Power \& Light Co., 435 U.S. 389, 410 (1978) (opinion of Brennan, J.)). In Midcal, the Court denied antitrust immunity for California's wine pricing system because there was no state supervision of the private anticompetitive activity involved in the resale price maintenance scheme. 445 U.S. at 105-06.

Anticompetitive actions taken by municipal governments are illegal unless they are pursuant to a "clearly articulated and affirmatively expressed' state policy to displace competition with regulation," Town of Hallie v. City of Eau Claire, 105 S. Ct. 1713, 1719 (1985), although such actions need not be compelled or supervised by the state. Id. at 1720-21. Thus local governments are not immune whenever they go beyond their state delegated authority, or engage in anticompetitive conduct within their authority but without a sufficiently clear state policy authorizing those actions. The Local Government Antitrust Act of 1984, Pub. L. No. 98-544, \&\$ 3-4, 98 Stat. 2750, 2750 (to be codified at 15 U.S.C. $\$ \S 35-36$ ), exempts local governments from damages liability for antitrust violations, but does not eliminate the availability of injunctive remedies. Thus the immunity standard proposed in this Note is of even greater importance as a means to limit government conduct that remains illegal, yet is not subject to the deterrent force of damages liability. An immunity standard that takes into account the invalidity of the governmental action might reduce this conduct by reducing the pressure on local government bodies to act in invalid ways.

66. For examples, see cases cited supra at note 47 and infra at note 79 . 
therefore cause direct injury to competitors far outweighing whatever benefit arises from the petitioning. ${ }^{87}$

\section{Proposed Limitation to Noerr-Pennington}

Dealing effectively with the imperfections of Noerr-Pennington immunity without significantly impinging on the structural and First Amendment concerns that gave rise to the Noerr doctrine requires a careful balancing that the doctrine is unable to make. To determine whether blanket immunity should be granted, the Noerr doctrine looks only to whether there is some bona fide motivation for petitioning, not to the seriousness and inevitability of direct injury or the legality of the desired governmental result. ${ }^{\text {8s }}$ Because of this conceptual shortcoming, injury to competition is tolerated in situations where a more precise immunity standard would minimize injury without endangering the ability of groups effectively to petition government to take legitimate action. The concern for maximizing competition mandates the adoption of a narrower immunity standard-if one can be fashioned without infringing First Amendment rights. ${ }^{69}$

\section{A. Criteria for Limiting Petitioning Immunity}

Attempts to address the flaws and limitations of the sham, commercial, and co-conspirator exceptions ${ }^{70}$ by dealing with the problems of unnecessary direct injury and illegitimate governmental action in isolation do not provide satisfactory solutions to either problem. Because, as Noerr recognized, some amount of direct injury is incidental to all petitioning, an immunity standard must condemn only that petitioning activity which produces unnecessary direct injury and thus a net social loss. However, an effort to devise a judicial standard that would deny immunity whenever

67. Much of the predation that occurs through the use of governmental processes takes place "at local levels through misuse of state and municipal procedures." R. BoRk, supra note 21, at 348 . Handler notes that there has been much concern "that legislatures at the state and municipal levels ... had been sheltering conduct that, absent state action immunity, clearly would contravene the antitrust laws." Handler, Reforming the Antitrust Laws, 82 Colum. L. REv. 1287, 1331 (1982). As of 1984 there were 200 antitrust damages actions pending against municipalities. 130 CoNG. REC. H12185 (daily ed. Oct. 11, 1984) (statement of Rep. Porter). Of course, the pendency of damages actions is only a circumstantial index of the degree to which local government bodies are violating the antitrust laws.

68. The inefficiency of such a standard is analogous to that of a negligence rule of liability when the standard of care does not take into account a relevant aspect of the injurer's behavior. See A. Polinsky, AN INTRODUCTION TO LAW AND ECONOMICS 46 (1983).

69. See City of Lafayette v. Louisiana Power \& Light Co., 435 U.S. 389, 398, 400 (1978) (because Congress "exercis[ed] the full extent of its constitutional power" in enacting Sherman Act, "recognized exclusions [from liability] have been unavailing to prevent antitrust enforcement which, though implicating th[e] fundamental policies [underlying the exclusions], was not thought severely to impinge upon them").

70. As discussed supra at notes 16-17, 57-63 and accompanying text, these doctrines seem to represent attempts to address these problems. 
direct injury could be avoided by use of a less-injurious petitioning technique would require a cumbersome and uncertain case-by-case analysis of particular petitioning efforts. ${ }^{71}$ For a court to determine in each case how much direct injury a group should be allowed to inflict to achieve a desired governmental response, and for a group's liability to hinge solely upon that determination, would create an uncertain standard that might chill socially desirable, and constitutionally protected, activity. Moreover, because such judicial balancing could not engage in a speaker-by-speaker application of First Amendment guarantees to determine how valuable a particular form of petitioning is to the actors involved in a particular case, it would be incapable of reaching an accurate calculation of how much direct injury must be tolerated in order to satisfy fully a speaker's First Amendment interests.

Similarly, the application of the Noerr-Pennington doctrine cannot properly serve its goals if it bases a denial of petitioning immunity solely on the invalidity of the governmental action sought. Petitioning directed at invalid governmental action is not entirely without value to society. ${ }^{72}$ Moreover, because the constitutional basis for the Noerr exception prohibits an undue chilling effect on petitioning, petitioners should not be forced to guess whether the action they seek will be valid. ${ }^{33}$

71. Areeda and Turner see the sham exception as leaving a "safety route" for imposing liability on unnecessarily harmful political activity. P. AREEDA \& D. TURNER, ANTITRUST LAw II 205, at 51-52 (1978). The authors articulate three factors on which courts should focus in determining the "indispensability" of such conduct: "(i) the severity of the danger to competition, (ii) the obviousness of a less dangerous alternative, and (iii) the customary political-character of the challenged behavior." Id. I 205, at 52. Their analysis, by operating within the sham exception, must ultimately focus on the genuineness of the defendants' efforts to solicit governmental action.

See also Note, Physician Influence: Applying Noerr-Pennington to the Medical Profession, 1978 Duke L.J. 701, 706-07 (outlining case-by-case test, like that undertaken in free speech cases, that would balance harms from direct injury against importance of petitioning and availability of alternatives in situations where "influencing activity used is in itself anticompetitive"). Relative to the standard proposed in this Note, the approach of Areeda and Turner and the Duke Note, by not also predicating denial of immunity on the invalidity of the governmental action sought, would create a standard that would not balance the relevant interests as efficiently, would rely on a case-by-case judicial balancing in each instance, and would entail a more serious chilling effect on legitimate activity.

72. See supra note 50.

73. See Subscription Television, Inc. v. Southern Cal. Theatre Owners Ass'n, 576 F.2d 230, 233 (9th Cir. 1978); P. AReedA \& D. TuRner, supra note 71, I 202b, at 39; $c f$. Comment, NoerrPennington Antitrust Immunity and Proprietary Government Activity, 1981 ARIz. ST. L.J. 749, 766 (concluding that exception to Noerr for efforts to influence government acting in commercial capacity would be too uncertain to avoid unacceptable chilling effect because of inexact definition of "commercial" behavior). Bern, however, would allow the validity of the governmental action sought to be taken into account by examining the government agency's "apparent authority." Bern, supra note 55, at 302. Immunity would be denied only when an agency's "mistakes are . . . so obvious that everyone should know that authority was absent." Id. (quoting P. AREEDA \& D. TuRNER, supra note 71, II $217 \mathrm{~b} 4$, at 113). This analysis seems to embody a traditional "sham" standard. See also Greenwood Utilities Comm'n v. Mississippi Power Co., 751 F.2d 1484, 1500 (5th Cir. 1985) ("Only where the evidence shows that the defendant knew or should have known that the action he sought was improper would a court be justified in labeling his petitions a 'sham' . . . ."). 
Addressing separately the twin problems of direct injury and invalid governmental action simply will not work without resulting in an inaccurate calculation of what amount of direct injury is appropriate. Petitioning in many forms is something that our society is constitutionally obliged to encourage. An effort to devise a legal rule that eliminates all petitioning that causes excess direct injury or seeks invalid governmental results requires drawing imperfect and unclear lines that will both lead to an inefficient amount of direct injury and inevitably result in the deterrence of some desirable petitioning. Courts cannot give adequate notice of what conduct will be subject to liability because they cannot simply command what methods of petitioning will be tolerated in various future circumstances or indicate $a$ priori what sorts of governmental action will ultimately be found invalid.

\section{B. A Standard for Limiting Immunity}

A workable immunity standard must thus focus on more than one aspect of the petitioning activity, and must create a framework in which the legality of petitioning can be determined with some accuracy before the petitioning takes place.

\section{The Nature of the Standard}

This Note proposes that defendants be denied immunity for directly injurious petitioning where adequate, less-injurious alternatives are available and the governmental action sought is illegitimate. ${ }^{74}$ In practice plaintiffs would establish a prima facie case by alleging three elements: direct injury, any alternative method of joint petitioning for the same governmental result (other than deciding not to petition) that would reduce the direct injury, and the invalidity of the result sought. Proof of these elements would give rise to a presumption of antitrust liability, rebuttable

74. The proposed standard would supplement the sham exception by permitting the imposition of liability for non-sham petitioning. An alternative, though less accurate, formulation of this standard would be to treat instances where the plaintiff establishes the three elements as creating an evidentiary presumption that the petitioning was used as a pretext for inflicting direct injury. Hence, the conduct would be denied immunity under the existing sham exception. The standard articulated in this Note would involve a legal standard that establishes an irrebutable presumption. This formulation is somewhat artificial in that the conduct reached would not usually involve purely sham activity, as defined by existing law (although it often would reach sham activity that slips through the cracks of the difficult-to-prove and imprecise existing standard). See supra notes 28-32 and accompanying text.

The use of a conclusive presumption in criminal antitrust cases would pose serious due process questions. See Sandstrom v. Montana, 442 U.S. 510, 523 (1979) (conclusive presumptions in criminal law conflict with overriding presumption of innocence). Nevertheless, in the civil antitrust actions that represent the vast bulk of cases implicating this limitation of Noerr-Pennington immunity, the articulation of such a presumption would allow courts easily to fit the standard within the conceptual framework of existing law. See R. POSNER \& F. EASTERBROOK, ANTrTruSt 533, 534 n.4 (2d ed. 1981) (97\% of antitrust actions brought in 1980 were civil actions). 
only if defendants could prove that the alternatives alleged would have been inadequate or that the invalidity of the result sought was unknowable. ${ }^{76}$ This standard would strike a more appropriate balance between the minimization of direct injury caused by petitioning and the exercise of petitioning rights.

The proposed immunity standard would have two general effects. First, the standard would impose liability for the most undesirable sort of petitioning that currently falls short of the sham exception-that which seeks invalid action and involves unnecessary direct injury. ${ }^{76}$ Any imprecision involved in case-by-case adjudication would not impede the standard's impact. ${ }^{77}$ Courts are accustomed to considering the adequacy of alternative channels of expression when analyzing time, place and manner restrictions, ${ }^{78}$ and they are frequently asked to consider the legitimacy of governmental action, even in litigation not brought against government entities. ${ }^{79}$

Second, and more important, possible liability for non-sham petitioning would force groups engaged in ostensibly bona fide petitioning to explore the practical consequences of their preferred means of influencing government. Although liability would be imposed only if all elements of the three-prong standard were satisfied, evidence of alternative petitioning methods and illegitimate governmental action would become legally relevant, and petitioners would have incentives to act in ways that would avoid satisfying these elements. The benefits of this standard would thus stem not only from the case-by-case balancing of interests undertaken

75. See infra note 99.

76. It is difficult to estimate whether this standard would have changed the outcome of many of the cases that have applied the Noerr-Pennington doctrine. Because the factors are not now legally relevant, the facts of these cases generally are not sufficiently developed to reveal unnecessary direct injury or the pursuit of an invalid response. An example of conduct reached by the proposed standard that would be immunized under current law is efforts entailing both direct appeals and a publicity campaign, or multiple efforts, by a group of local broadcasters to convince some local government body to deny an application for a cable television franchise when the local government has not been given adequate state authorization to contravene the competitive process. Under current law a plaintiff "would have to establish that the efforts to convince the local government body to take this action were "a mere sham."

77. The actual application of this standard in court would, of course, require case-by-case adjudication. The only relevant subjects of in-court factual determination, aside from direct injury, would be whether there was some less-injurious way of petitioning and whether the governmental action sought would have been invalid. These inquiries may create some imprecision and uncertainty, but they will improve the balance of interests under Noerr-Pennington.

78. See supra note 40 and accompanying text.

79. See, e.g., California Retail Liquor Dealers Ass'n v. Midcal Aluminum, Inc., 445 U.S. 97 , 105-06 (1980) (Court denied Parker immunity to state program of fair trade regulation and thus to private parties acting within program, despite fact that state was before Court only as amicus curiae); Cantor v. Detroit Edison Co., 428 U.S. 579, 582-85 (1976) (in antitrust action brought against electric utility, Court looked to power, authority, and regulatory actions of public service commission that was never party in order to find commission's implicit regulatory approval insufficient to extend immunity to utility's conduct). See also infra note 102 (courts characterize capacity in which government operated when applying existing Noerr-Pennington exceptions). 
when immunity is denied, but also from the creation of an incentive for petitioners to modify their behavior by choosing less harmful means of petitioning or by concentrating their efforts on seeking only valid governmental action.

\section{Internalizing Proper Considerations to Achieve the Appropriate Level of Direct Injury}

The first predicate for potential antitrust liability-infliction of some direct anticompetitive injury - will be easy for petitioning groups to ascertain. ${ }^{80}$ Aware of this potential, groups will act to avoid liability. They can refrain from using methods that cause more "incidental" direct injury than necessary to seek a particular governmental response. The standard avoids this inquiry at the judicial level in each case because the potential defendants will internalize the inquiry in the face of possible liability.

Of course, alternative methods of petitioning may not always be equally effective. Thus, to achieve an efficient balance between the beneficial aspects of petitioning and the costs incurred by society when direct injury is inflicted, a more effective means of petitioning may be preferred even if it causes somewhat more direct injury. By allowing potential defendants to avoid liability by soliciting only valid governmental action, the standard attempts to internalize this balancing process. If particular harmful forms of petitioning, for which there may be less-effective but less-injurious alternatives, are especially preferred by a particular group, ${ }^{\mathbf{8 1}}$ they will be carried out only after the petitioners make some determination that the governmental action is valid, and thus that their petitioning will be immune under the third component of the proposed standard. ${ }^{\mathbf{2 2}}$

The effectiveness of this standard is greater than that achieved by existing law or by an alternative that examines individually the necessity of direct injury or the invalidity of the governmental action. In minimizing the costs of deterring some forms of petitioning activity (the costs of avoiding direct injury) and the costs of direct antitrust injury, ${ }^{83}$ some burden

80. See discussion infra at notes $95-96$.

81. If such petitioning is especially important only because it causes direct injury, it can be reached under the existing sham exception.

82. For example, groups preparing a petitioning campaign could seck legal advice (and would likely do so in any event) regarding the legitimacy of the regulatory body sought to be influenced, or perhaps the group could seek a declaratory judgment that the action sought would not result in antitrust liability.

83. Minimizing these costs is the fundamental goal of any system of liability involving reducible social costs. See G. Calabresi, The Costs of Accidents 26 (1970). Calabresi's analysis is not precisely analogous because he does not deal with constitutionally protected values. However, the balancing required in all First Amendment analysis is still benefitted by having the appropriate participant evaluate the various costs and take the proper steps to reduce them in order to achieve an efficient outcome. The constitutional provision can be viewed as providing a constraint on the kind of process that implements this balancing much like "justice" can impose a veto on certain systems of 
should be placed on the party best positioned to weigh and reduce these costs. ${ }^{84}$ Instead of engaging in case-by-case judicial balancing in every situation, or ignoring the direct injury, the antitrust laws will cause business enterprises to weigh the relative importance of the various forms of petitioning against the potential costs of antitrust liability before acting. In so doing they will strike a more appropriate balance than the law now produces. ${ }^{8 s}$

\section{B. The Proposed Standard Would Not Violate the First Amendment}

\section{Encouraging Less-Injurious Petitioning Represents a Proper Manner Restriction}

Because the proposed standard to regulate this injurious petitioning activity will allow a finding of liability only when unnecessary direct injury is inflicted, antitrust liability will not be imposed in violation of the First Amendment. ${ }^{86}$ This conclusion is made even more clear by the fact that liability will never be imposed unless the governmental response sought is illegitimate, in which case the First Amendment interests in the free flow of information that have led the Court to extend some protection to commercial and corporate speech are substantially lessened..$^{\mathbf{8 7}}$

Basing liability in part on the illegitimacy of the action sought does not deprive the standard of its status as a reasonable content-neutral manner restriction. Any relationship of liability to the content of petitioners' messages is merely a correlation between certain messages (those seeking illegitimate governmental action) and the harm that the antitrust laws seek to prevent. ${ }^{88}$ The standard does not entail an impermissible classifi-

accident cost reduction in Calabresi's analysis. Id. at 25 .

84. Cf. id. at 135 (advocating "allocation of accident costs to those acts or activities . . . which could avoid the accident costs most cheaply").

85. Petitioners themselves, especially groups of business enterprises that are seeking economic gain through political and regulatory processes, are best positioned to evaluate the importance of their "petitioning rights," to search for alternatives that will achieve the results that they want, and to analyze the validity of the governmental action that they seek. See infra note 95 and accompanying text.

86. See discussion supra at notes 34-46 and accompanying text.

87. See discussion supra at notes 48-52 and accompanying text. Indeed, the Supreme Court has already engaged in First Amendment analysis closely analogous to that urged in this Note. In Giboney v. Empire Storage \& Ice Co., 336 U.S. 490 (1949), a union picketed Empire to persuade them to agree not to sell to nonunion vendors. Virtually all of the elements of the petitioning conduct addressed in this Note were present: the peaceful picketing "to publicize truthful facts about a labor dispute," id. at 498, was constitutionally protected activity, it caused direct injury in the form of loss of business to Empire, and it sought an illegal result-a group boycott. The Court concluded that it was within the state's power to pass a law outlawing the direct injury caused by the picketing and that First Amendment immunity does not extend to speech used as an integral part of injurious conduct in violation of a valid statute. Id. at 501-02.

88. Any relationship to content is only in the irrelevant sense that restrictions on expressive conduct in furtherance of criminal, as opposed to harmless, conspiracies are content related. For example, the regulation prohibiting draftcard burning upheld in United States v. O'Brien, 391 U.S. 367 (1968), 
cation based on the speaker's viewpoint ${ }^{89}$ or serve a governmental interest aimed at the suppression of protected activity ${ }^{90}$ Consequently, the statute does not create a danger that it will be applied in an overbroad manner to conduct that is entitled to First Amendment protection.

\section{The Proposed Standard Will Not Unduly Chill Protected Activity}

The proposed standard thus is a proper regulation of conduct under the First Amendment. The only remaining First Amendment issue posed by the standard, then, is whether uncertainty regarding what petitioning remains protected would unduly chill petitioning that does not cause an inappropriate amount of direct injury. ${ }^{91}$ The fact that the petitioning addressed is economically motivated suggests that it is unlikely to be chilled to any significant extent by the proposed standard. ${ }^{92}$ The Supreme Court has noted that individuals contemplating commercially motivated speech will not be discouraged by mere uncertainty in the law. ${ }^{93}$ Petitioning subject to the proposed liability rule would be similarly hardy because it too is financially motivated-by a desire to exclude or harm competitors and thereby to protect or seek monopoly profits for the existing group. ${ }^{94}$ It would be carefully planned activity entered into only after a careful analysis of the costs and benefits, which would certainly include an analysis of the legal risks involved. ${ }^{95}$ Thus, protected conduct is unlikely to be substantially chilled by any uncertainty in the standard.

necessarily impinged only upon the expressive activity of those opposed to the Vietnam War.

89. See Members of the City Council v. Taxpayers for Vincent, 466 U.S. 789, 804 (1984) (prohibition of cardboard signs on utility poles during political campaigns when most such signs relate to advocacy of particular candidate is "viewpoint-neutral" and satisfies O'Brien test).

90. Unlike the interest in Virginia State Bd. of Pharmacy v. Virginia Citizens Consumer Council, Inc., 425 U.S. 748, 769-70 (1976), which was predicated on reducing the information available to consumers, the governmental interest here is plainly not aimed at reducing the information available to government; rather it is aimed at reducing direct injury to competition. See supra note 39 and accompanying text.

91. See supra note 73 and accompanying text. A challenge to this standard would thus be phrased in terms of "void-for-vagueness" doctrine. See L. Tribe, American Constitutional Law §§ 12-26, 28 (1978).

92. Because the proposed standard would not impose "new" liability for any conduct currently immune regardless of Noerr-Pennington protection, the sort of politically motivated anticompetitive activity that is protected under the Supreme Court's recent holding in NAACP v. Claiborne Hardware Co., 458 U.S. 886, 913 (1982), would not be reached by the standard. The economically motivated activity that is reached will not be significantly chilled because all economic activity is inframarginal-undertaken $u p$ to the level at which marginal costs equal marginal benefits. All such activity, except the last marginal increment, thus produces positive net returns and will still be undertaken despite some reduction in its expected return caused by a threat of liability.

93. Bates v. State Bar, 433 U.S. 350, 380-81 (1977) (holding overbreadth doctrine inapplicable to commercial speech, Court noted "[s]ince advertising is linked to commercial well-being, it seems unlikely that such speech is particularly susceptible to being crushed by [the uncertainty inherent in] overbroad regulation").

94. The activity protected by Noerr-Pennington is motivated by a desire by petitioners to "bring about an advantage to themselves and a disadvantage to their competitors." Noerr, 365 U.S. at 139.

95. In United States v. United States Gypsum Co., 438 U.S. 422, 445-46 (1978), the Court 
The proposed standard sets forth clear guidelines for these economic actors, enabling them to distinguish conduct that can form the basis of liability from that to which immunity must be granted. Most clearly, the standard will retain the threshold requirement of any antitrust liability, and provide a certain grant of immunity when there is no direct injury. Because private parties will know when their conduct causes such injury, ${ }^{96}$ the questions facing a potential defendant will be whether there is some feasible, less-injurious form of petitioning which he can pursue and whether the governmental response will be valid.

It will often be clear to petitioners that these other elements are not satisfied and thus that the mere presence of direct injury will not result in a denial of immunity. In general, the uncertainty regarding alternative means of petitioning will be insubstantial. Petitioners serious enough about achieving anticompetitive results through petitioning so as to band together will be aware of the panoply of alternatives available to produce those results. Moreover, certain classes of petitioning methods will not raise serious doubts regarding the lack of acceptable alternatives. For example, a single suit that both seeks a ruling harming a competitor and also causes direct expense will probably not be subject to the rule because the direct injury would ordinarily be an unavoidable effect of the only "petitioning" method (a lawsuit) capable of achieving that ruling. And while petitioners will always have the option of petitioning individually, the proposed standard is not intended to consider individual petitioning a less-injurious alternative available to the group. ${ }^{\text {iz }}$

indicated that "[t]he business behavior which is likely to give rise to criminal antitrust charges is conscious behavior normally undertaken only after a full consideration of the desired results and a weighing of the costs, benefits, and risks." But see Fischel, supra note 9, at 102-103 ("[I]t is doubtful that such activity is as durable as advertising-the paradigmatic form of commercial speech. Often the risk of treble damage liability will outweigh the expectation of returns from petitioning activity."). Fischel, however, does not provide any support for this conclusion. There is every reason to believe that economically motivated petitioning of the kind addressed by the proposed standard will be hardy enough to withstand some uncertainty; petitioners will be seeking monopoly returns, not merely the revenues from product sales within the competitive market that advertising might reap.

96. See Noerr, 365 U.S. at 143 (direct injury is often inevitable, and "it seems equally inevitable that those conducting the campaign would be aware of, and possibly even pleased by, the prospect of such injury") (emphasis added).

97. The ability of the members of trade associations and other groups of competitors to petition individually without implicating antitrust principles, see supra note 7 , could suggest that there will always be a less-injurious alternative means of petitioning available. Courts, however, have generally extended considerable protection to First Amendment association rights when the purpose of the association is to engage in activity that would be constitutionally protected if engaged in individually. Roberts v. United States Jaycees, 104 S. Ct. 3244, 3252 (1984). Thus, such a conception of "adequate alternative" would pose serious constitutional questions, and would also be conceptually inconsistent with the very foundation upon which Noerr was decided. For these reasons, this Note does not envision that such individual petitioning would be a "feasible less-injurious alternative" under the proposed immunity standard. But see Kintner \& Bauer, supra note 17, at 553 ("although the individual right to petition deserves protection, it is not equally clear that the first amendment and its associated values require that persons be allowed to act jointly in a 'combination or conspiracy' to seek such 
Also, in certain situations it will be clear that the governmental result sought would be legitimate. Most lobbying of Congress and state legislatures will fall into this category. There is little regulatory action that is beyond the authority and antitrust immunity of these bodies. ${ }^{98}$ Moreover, because the standard would not encompass situations in which the invalidity of a particular type of governmental action was impossible to know when the direct injury was inflicted, ${ }^{9 \theta}$ legislative acts later held unconstitutional would usually fall outside the definition of "invalid" action.

Within this limited range of uncertainty, much of the conduct that will be deterred is not entitled to First Amendment protection, even if liability would not have been imposed had petitioners proceeded with their efforts. Because this conduct will always cause direct injury, society benefits from an antecedent examination into both the availability of alternatives and the legality of the result sought, even if the petitioning is ultimately deemed to warrant First Amendment protection. When firms decide not to petition without conducting these reasonable inquiries, their behavior reveals that the benefits of the petitioning activity are not sufficiently important to override antitrust policies. ${ }^{100}$

Improper chilling would only occur if petitioners analyzed both the existence of alternatives and the invalidity of the governmental action sought, and incorrectly determined that immunity would be denied. But because there are two independent ways to avoid liability, the likelihood that prospective petitioners will overestimate both of these criteria will be

relief'). Groups unwilling to take other steps to reduce the direct injury they cause or unwilling to make sure that governmental action will be valid would always be free to avoid liability by petitioning independently. Of course, they would not necessarily be free to agree to petition independently.

98. See discussion of Parker doctrine, supra note 53. Congress, of course, has the power to repeal the antitrust laws. See Gordon v. New York Stock Exch., Inc., 422 U.S. 659, 682 (1982) (implied repeal by Securities Exchange Act).

99. That there will be some uncertainty in estimating the validity of governmental action cannot be denied. Commentators have recognized that the cases applying the state action exception are not entirely predictable. See H.R. REP. No. 965, 98th Cong., 2d Sess. 7 n.7, reprinted in 1984 U.S. Code CONG. \& AD. NEws 4602, 4608 n.7 (Court "has ruled in different ways in closely similar settings"); see also In Re Airport Car Rental Antitrust Litig., 521 F. Supp. 568, 584-85 (N.D. Cal. 1981) (petitioners cannot predict "whether officials or their agencies could in some future lawsuit be held liable under the antitrust laws"), aff d, 693 F.2d 84 (9th Cir. 1982), cert. denied, 462 U.S. 1133 (1983). The proposed standard, however, would avoid much of this problem by not addressing conduct in which the elements necessary to overcome immunity were unknowable to petitioners. The test would not examine the actual state of the defendant's knowledge when it undertook its petitioning efforts, but would examine what the defendant should have known had it made the necessary inquiries. When, for example, judicial holdings or facts relevant to the constitutionality or validity of certain governmental action do not exist at the time of the petitioning conduct in question, the proposed rule would not deny Noerr immunity.

100. Because society wants these inquiries made, this deterrent effect is desirable, and thus cannot be characterized as "chilling" to constitutional rights. The deterrent effect is similar to that discussed in United States $v$. Harriss, where the Court dismissed the claim that vagueness would cause persons to refrain from protected petitioning activity in "borderline situations": "the restraint is at most an indirect one resulting from self-censorship, comparable in many ways to the restraint resulting from criminal libel laws" and the Hatch Act. 347 U.S. 612, 626 \& n.17 (1954). 
small. The clear provisions of the standard thus draw a line sufficiently far from protected activity to prevent any uncertainty concerning its application from having an undesirable chilling effect.

In addition, although even minimal chilling is undesirable, it is important to recognize that the existing immunity standards, upheld against First Amendment claims, are no less uncertain and thus no less chilling than the proposed standard. The sham and commercial exceptions have quite varied application and unknown reach. ${ }^{101}$ The scope of the sham exception can often vary radically depending upon a court's characterization of a government body as legislative or adjudicatory. The commercial and co-conspirator exceptions depend on a judicial characterization of government activity as "proprietary" or "complicitous," respectively. With these exceptions, the current Noerr-Pennington doctrine already requires petitioning groups to make a difficult and uncertain judgment about the capacity in which government will later be deemed to have operated. ${ }^{\mathbf{2 0 2}}$ Because some petitioning may lead to liability, groups must already pause to consider this threat.

Any insubstantial chilling that does result cannot invalidate a standard that actually imposes liability only upon conduct undeserving of protection. ${ }^{103}$ Recent Supreme Court opinions express the view that laws should not be voided on their face unless deterrence of protected speech is significant. ${ }^{104}$ In applying the void-for-vagueness doctrine, the Court has con-

101. See Greenwood Utilities Comm'n v. Mississippi Power Co., 751 F.2d 1484, 1498 (5th Cir. 1985) ("precise contours of these [sham] exceptions are as yet ill-defined"); Dollar Rent A Car Sys. v. Hertz Corp., 434 F. Supp. 513, 516 (N.D. Cal. 1977) ("exact contours of the Noerr-Pennington exception are unclear"); Fischel, supra note 9, at 104 ("determination of whether petitioning activity is a sham ... has been plagued by considerable confusion").

102. See In Re Airport Car Rental Antitrust Litig., 693 F.2d 84, 88 (9th Cir. 1982) ("nature of the government activity is one factor in determining the type of public input acceptable to the particular decision-making process"), cert. denied, 462 U.S. 1133 (1983); Franchise Realty Interstate Corp. v. San Francisco Local Joint Exec. Bd. of Culinary Workers, 542 F.2d 1076, 1087 n.1 (9th Cir. 1976) (dissenting opinion) (court characterized San Francisco Board of Permit Appeals as legislative body, although plaintiff's complaint alleged that it was adjudicatory; dissent noted that question could not be resolved on existing record, and that "distinction is crucial"), cert. denied, 430 U.S. 940 (1977); Metro Cable Co. v. CATV of Rockford, Inc., 516 F.2d 220, 228-32 (7th Cir. 1975) (court's characterization of city council as legislative body crucial in determining application of co-conspirator exception and effect of claims of access denial); Comment, supra note 73, at 766 (application of any commercial exception ambiguous and chilling); see also Dollar Rent A Car, 434 F. Supp. at 517 (defendants correct in admitting that "savailability . . . of . . . Noerr defenses . . . will require proof at trial on an airport-by-airport basis" "and "thorough and detailed examination of all circumstances surrounding the particular governmental action and competitive foreclosure at issue" ").

103. See Kintner \& Bauer, supra note 17, at 582 (some chilling tolerable in order to serve antitrust policies).

104. In Broadrick v. Oklahoma, 413 U.S. 601, 615 (1973), the Court noted that "[a]lthough [valid criminal] laws, if 100 broadly worded, may deter protected speech to some unknown extent, there comes a point where that effect-at best a prediction-cannot, with confidence, justify invalidating a statute on its face .... [W]here conduct and not merely speech is involved, we believe that the overbreadth of a statute must not only be real, but substantial as well, judged in relation to the statute's plainly legitimate sweep." The Court thus rejected the challenge to Oklahoma's restriction on 
sistently held that the deterrence effect of a vague statute must be real and substantial. ${ }^{105}$ Similarly, the Court has expressed skepticism toward the reality and significance of deterrence caused by laws implicating First Amendment rights. ${ }^{108}$ Consequently, requiring potential petitioners to internalize the inquiries into alternative petitioning methods and the illegitimacy of the governmental result they seek will not unduly chill petitioning that deserves First Amendment protection.

\section{CoNCLUSION}

By failing to take into account the inevitability of direct injury inflicted and the illegitimacy of governmental action sought by collusive petitioning activities, the Noerr-Pennington doctrine unnecessarily tolerates a dangerous amount of injurious conduct. This Note proposes a standard that denies immunity where less-injurious alternatives are available and the governmental action sought is invalid. Such a standard will internalize the inquiry into less-injurious means of petitioning, and so better serve the fundamental interests of the Sherman Act, without unduly conflicting with the policies, both constitutional and structural, underlying the existing Noerr-Pennington doctrine.

political activities of state employees, concluding that "we do not believe that [the statute] must be discarded in toto because some persons' arguably protected conduct may or may not be caught or chilled by the statute." Id. at 618 .

105. See Young v. American Mini Theatres, Inc., 427 U.S. 50, 59-61 (1976) (ordinance not unconstitutionally vague because Court not persuaded that it would "have a significant deterrent effect on the exhibition of films protected by the First Amendment"); Harriss, 347 U.S. at 626 (noting hypothetical situations involving chilling, but concluding that "hazard . . . is too remote").

106. See, e.g., Branzburg v. Hayes, 408 U.S. 665, 698-70 (1972) (dismissing claims that collection and dissemination of news would be deterred without constitutional protection for press informants); Laird v. Tatum, 408 U.S. 1, 13-14 (1972) (rejecting claim that First Amendment rights were chilled by existence of Army data-gathering system on grounds that respondent made no showing of "specific present objective harm or a threat of specific future harm"). 